\title{
A scholarly tradition continued
}

\section{Journal Article}

\section{Author(s):}

Vickers, Brian

Publication date:

1991

Permanent link:

https://doi.org/10.3929/ethz-b-000423053

Rights / license:

In Copyright - Non-Commercial Use Permitted

Originally published in:

The British Journal for the History of Science 24(3), https://doi.org/10.1017/S0007087400027394 


\section{Essay review}

\section{A scholarly tradition continued}

John Henry and Sarah Hutton (eds.), New Perspectives on Renaissance Thought: Essays in the History of Science, Education and Philosophy in Memory of Charles B. Schmitt. London: Duckworth and Istituto Italiano per gli Studi Filosofici, 1990. Pp. $x+324$. ISBN 0-7156-2248$\mathrm{X}$.

This volume derives from a memorial symposium held at the Warburg Institute in February 1987 to commemorate Charles Schmitt's untimely death in April 1986, at the age of fiftythree. The range of institutions which supported the colloquium shows the width of Charles's interests, and the respect with which he was held: in addition to the Warburg, where he had taught for thirteen years, the Istituto Italiano per gli Studi Filosofici (joint publishers of this volume), the British Society for the History of Science, the British Society for the History of Philosophy, the British Society for the History of Mathematics, the Society for Renaissance Studies, Oxford University Press for the journal History of Universities (which Charles founded in 1981), the British Academy, the Royal Society, and the Wellcome Trust. It is difficult to think of many scholars so active - indeed outstandingly so - in such a range of disciplines. As the editors say in the introduction, Charles Schmitt had 'an unificationist view of Renaissance intellectual history', an inspiring example to all who work in this field to follow the authors they study and ignore the subject boundaries so constricting in modern universities. This volume, handsomely produced and printed, ${ }^{1}$ contains seventeen papers of an unusually high quality which cover

1 The following misprints can be noted: p. 6 n. 24 , for $\mathrm{n} .19 \mathrm{read} 18 ; \mathrm{p} .14 \mathrm{n} .9$, for consenu read consensu; p. 31 n. 27 , for astronomci read astronomici; p. $36 \mathrm{n}$. 49, for th read the; p. 49 n. 4, for succint read succinct; p. 96 n. 45 , replace period before Hamlet with a semicolon; p. 127 n. 91 , for 197 read 1977 ; p. 131 n. 108 , the most of Charles Schmitt's interests and constitute an admirable tribute to the range and depth of his work.

\section{1}

Pride of place ought to go to the five papers on Renaissance Aristotelianism, arguably the area where Charles Schmitt did his most important and influential work. Richard Sorabji, 'Infinite power impressed: the transformation of Aristotle's physics and theology', reconstructs the views of the Neoplatonist commentator Ammonius (c. 435/45-c. 517/26), a pupil of Proclus whose own pupils included Philoponus, and who wrote a whole book maintaining that Aristotle made 'God the efficient cause of the world', that is 'casually [sic] responsible for its beginningless existence'. The crucial texts are from the Physics, where Aristotle argues that 'what produces unending motion must be infinite', and the Metaphysics, where the mover is said to be God, who alone 'can supply the required infinite power'. Sorabji traces the commentary tradition on these ideas in Philo. ponus, in a newly-assigned text by Avicenna, in Averroes and Aquinas, before discussing its implications for Aristorle's theory of dynamics. Sorabji himself says that 'Avicenna's argument is hard to follow', nor are the other texts easier, but the author's characteristic verve and clarity in exposition help the reader.

Less successful in clarity and organization is John E. Murdoch's paper, 'From the medieval to the Renaissance Aristotle', where the learned detail somctimes obscures the argument. Basing himself on expositions of the Physics, especially

word Alie should read allied; p. 139 line 12, for indispensible read indispensable; p. 141 line 2, for casually read causally; p. 172 line 25 , for affectations rcad affections; $p$. 248 line 6 , for exorted read cxhorted; p. 273 line 31 , for slipperyness read slipperiness; p. 308 ine 1, for THES read TLS. 
Book 6, Murdoch's survey concludes that 'there is almost no new argument in the Renaissance material... which was not also present in the relevant medieval material'. The differences derive in part from what Charles Schmitt identified as the change from scholastic commentaries (philosophical, analytical) to humanist ones (philological), which easily absorb material from non-Aristotelian sources, resulting in a characteristically Renaissance eclecticism. It was precisely this openness to other influences, Murdoch emphasizes, that made Renaissance Aristotelianism capable of growth, 'able to absorb new ideas and developments'. It is significant that Renaissance Aristotelians could and did import new mathematical methods, but did not take over medieval logic: recognition, I would argue, of their awareness of the need to re-focus scientific methodology from verba to res, seen later in Francis Bacon's attacks on the word-centred nature of both syllogistic and inductive logic in the scholastic tradition. Murdoch ends by discussing motion and the Ockhamist particularist ontology.

Eckhard Kessler, in 'The transformation of Aristotelianism during the Renaissance', pays tribute to Charles Schmitt's 1971 bibliography of Renaissance Aristotelianism as marking the turning-point in the rehabilitation of Aristotle as a positive influence on Renaissance philosophy. Kessler notes how Aristotelian physics was freed from metaphysical limitations to become 'a truly empirical science of nature', as in Galileo's lessons from his Jesuit teachers (the work of William Wallace is given due acknowledgement here as in other papers). In addition, Kessler shows, Aristotelianism was not opposed to Platonism in the Renaissance, as is commonly thought, but was in continual dialogue with it. Nor was the humanism anti-Aristotelian per se, though it did call for Aristotle's transformation from a speculative to an empirical philosopher. Where Murdoch's paper contained too much detail, Kessler's has not enough to illustrate its argument, being rather dense and hard to extrapolate.

A much more successful balance between argument and illustration is reached by Stephen Pumfrey in 'New-Aristotelianism and the magnetic philosophy'. Drawing on Charles Schmitt's thesis that Aristotelianism was so long-lived because of its eclectic readiness 'to accept new developments', especially by its more progressive exponents (the Jesuits, above all), Pumfrey traces the reception of William Gilbert's De magnete. Two points in Gilbert's book received attention: first, that 'the Earth was also a magnetic sphere, not made of Aristotelian matter'; second, that a 'magnetic Earth... was in principle capable of Copernican revolution'. The first point challenged Aristotelian, the second Catholic orthodoxy. While the universities showed no interest in Gilbert (typical of their attitudes to the sciences before 1650), his ideas were taken up by the neo-Aristotelian Jesuits, who had broken away from the scholastic commentary tradition and were ready both to adopt un-scholastic tenets and to accept the need for empirical observation and experiment. Yet their openness had its limits: the Jesuit Niccolo Cabeo, in his Philosophia magnetica (1629), for example, absorbs much of Gilbert's philosophy, but rejects the Copernican implications. In the antiCopernican mood after Galileo's trial another Jesuit, Jacques Grandami, used Cabeo's work to attack Galileo and Kepler, devising an experiment that apparently proved the earth immobile, its apparent replicability once more revealing the dangers of reliance on misconstructed experiments. Finally, Pumfrey shows, the earth's movement was seen to be unconnected with its magnetism. This is a modest but coherent paper, economically fulfilling its promises.

Also well-integrated, but much more wideranging, is the paper by $\mathrm{L}$. W. B. Brockliss (who has succeeded Charles Schmitt as editor of History of Universities), 'Copernicus in the university: the French experience'. Drawing on the researches made for his outstanding study, French Higher Education in the Seventeenth and Eighteenth Centuries. A Cultural History (Oxford, 1987), Brockliss emphasizes the importance of the colleges de plein exercice, created in the sixteenth century, which had displaced the university arts faculties as teaching centres. Brockliss divides his survey (which covers so much ground that a few generations ago it could have been published as a monograph in its own right) into four main periods. Before 1640 
Copernicanism was either ignored or discussed as absurd, the geostatic Ptolemaic universe with its solid planetary spheres continuing to rule. Between 1640 and 1690 there was less hostility to Copernicanism, which was accepred as being optically satisfactory, but the Tychonic system, as a geocentric via media, was preferred. Professors in this period (with only one exception) were still prisoners of biblical literalism. From 1690 to 1760 qualitative physics was replaced by Cartesian mechanical philosophy, and to secular teachers heliocentricity seemed simpler, and therefore superior. The Jesuits, however, while supporting the mechanical philosophy also held on to Tychonism, their lecture courses being a weird amalgam of old and new. Finally, after 1760 Copernicanism triumphs, along with Newtonian cosmology, and we see in France 'for the first time... a generation of philosophers who felt that the realms of theology and natural philosophy were completely separate'. Francis Bacon's call for this separation, made 150 years earlier, was only then recognized.

Protestant countries, less subject to doctrinal constraint, had accepted Copernicanism as the superior cosmological theory by $1650-1700$. The delay in France, then, especially among the Jesuits, who were so much in the forefront of science in the time of Galileo, needs explaining. Brockliss notes that the recent revaluation of Jesuit science has reached the point that $\mathrm{J}$. L. Heilbron can claim that many members of the order, such as Athanius Kircher, were pioneers of the experimental philosophy. As Brockliss drily observes, 'revisionism may have now gone too far'. (Stephen Pumfrey justly observes that 'Kircher's voluminous tomes published everything, true and false.') The fact is that the Jesuits remained deaf to Copernicanism almost up to the collapse of their order in the 1760s and 1770 s, and were unimpressed by either the optical or mathematical arguments for heliocentricity. The crucial factor, Brockliss argues, was the internecine religious quarrel which arose in the 1650 s around the Jansenists, for whom the Pope had far exceeded his role as head of the Church in pronouncing heliocentricity absurd. The papacy now denounced both Copernicans and Jansenists, so that the Jesuits, staunchest allies of the Pope on this issue, became locked into an
anti-Copernican position. This prolonged quarrel also delayed the acceptance of the Cartesian mechanical philosophy, which in France was the determining factor in the acceptance of heliocentricity. This seems to me a coherent and convincing historical explanation, and one which admirably demonstrates the recent trend in the history of science to re-situate intellectual issues in their social, institutional, and doctrinal contexts.

\section{2}

The importance of reconstructing institutional contexts in the communication of knowledge is shown in five nicely varied papers. Thomas B. Settle, in 'Egnazio Danti and mathematical education in late sixteenth-century Florence', starts from the lectures given by Galileo in $\mathbf{1 5 8 8}$ to the Accademia Fiorentina on the shape, place and size of Dante's Inferno. The question he poses is, where did engineers and other practical men learn mathematics in late sixteenth-century Florence? The University had been moved to Pisa in the 1470s, apart from the chairs of rhetoric and poetics, and the role of instruction in practical arts, he shows, was taken over by the Accademia del Disegno, which, in addition to the expected courses in painting, sculpture and architecture, also taught anatomy and mathematics. The mathematics teaching was much broader than that offered at the University, including more subjects, both theoretical and practical, and was taught in the vernacular. The key figure before Galileo, Settle shows, was Egnazio Danti, a polymath appointed court cosmographer in 1563 and professor of mathematics 1571-75, who taught all the mathematics subjects, supervised the building of bridges, wrote a book on the use and construction of the astrolabe, built larger scientific instruments, and both designed and installed the globes in the Sala di Geografia of the Palazzo Vecchio. Settle's paper, based on many years' study of the intellectual setting of sixteenth-century Italy, and excellently documented, is a valuable corrective to the traditional image of the moribundity of Renaissance universities in the sciences. Competent teaching was available outside the faculties proper, as Mordecai Fein- 
gold recently showed for Oxford and Cambridge colleges. ${ }^{2}$

New light is shed on university teaching from a different, and surprising direction, by Vivian Nutton in a witty and learned paper, 'Medicine, diplomacy and finance: the prefaces to a Hippocratic commentary of 1541 '. The commentary, on Hippocrates' Aphorisms, was by the Ferrarese physician and professor of medicine Antonio Brasavola, and exists, intriguingly, with two separate prefaces. The first was dedicated to Henry VIII, after the fall of Thomas Cromwell in 1540 , in the pious desire to win him back to the Catholic fold. When that hope proved illusory, the author substituted a second preface in eigener Sache, addressed to the minister in charge of Ferrara University, who had quizzed Brasavola about the content of his lectures and the number of students attending them. Student numbers were down, professors had to justify their courses, so Brasavola listed fifty-four regular attenders, thus giving a unique insight into the make-up of a Renaissance university audience. Official university documents only record those students who entered and graduated, not who attended lectures, or who moved on before graduating. Nutton is able to reconstruct this audience, analysing it in terms of geographical catchment area and status. The most surprising feature is that many of the listeners were senior medics, twenty-eight with the MD, including two professors and six lecturers, which suggests that this course may have been more like a graduate seminar. The great range of statuses in the audience, from chair-holders and ducal physicians down to surgeons and a bone-setter, show again the homogeneous nature of medical teaching in Italy, compared to the stiffer social hierarchies in England. Admirably documented, this paper helps give us a definite picture of a social and intellectual area of which we otherwise have only a vague idea.

Real university life is studied by J.W. Binns in 'Elizabeth I and the universities', in particular the Queen's official visits to Cambridge in 1564,

2 See Feingold, The Mathematicians' Apprenticeship: Science, Universities and Society in England 1560-1640, Cambridge, 1984, and my review in Journal for the History of Astronomy, (1985), 16, pp. 56-9.
Oxford in 1566. Binns, a distinguished neoLatinist, pays special attention to the classical elements in these junketings, from sermons, disputations and orations in Latin and Greek all knowingly followed by the learned Queen to a Latin poem of some 3000 lines, the Regina liberata (1565) of Abraham Hartwell, which he describes as a 'fascinating' encomium. If the distance between present and past to all but the dedicated historian seems immense on such a point, all concerned with the state of British universities will feel a spark of recognition at John Case's words (in an Apologia academiarum written in the 1590 s but still in manuscript) defending universities as the eyes of the realm, and warning that 'a state that lacked universities and learned men was simply an abode of wolves and tyrants'. This is a useful contribution, but one may feel (unlike the majority of the papers here) that it could have offered rather more.

Nancy Siraisi bites off a large chunk of institutional and intellectual history in 'Medicine, physiology and anatomy in early sixteenthcentury critiques of the arts and sciences'. Her basic idea was to look at the discussion of medical topics in three polemical works from the 1520s: Gianfrancesco Pico della Mirandola, Examen vanitatis doctrinae gentium et veritatis Christianae disciplinae; Henry Cornelius Agrippa, De incertitudine et vanitate scientiarum declamatio invectiva; and Juan Luis Vives, De causis corruptarum artium and De tradendis disciplinis, part of his encyclopedic treatise on education, De disciplinis. The best section of her essay deals with Pico's sceptical attack on the absence of certain knowledge in physiology, with a 'rhetorical tour de force' on how the doctors disagree. The author's great knowledge of the medieval intellectual context illuminates this section, showing Pico drawing on a long tradition criticizing medicine going back to John of Salisbury, Dante and Petrarch. Cornelius Agrippa, for his 'attack' (whether or not seriously intended by the rhetorical term declamatio is much disputed), was happy to revive Hugh of St Victor's classification of medicine as a mechanical art, then categorizing rational medicine as dealing with words, not things, before finally dismissing Hippocrates and Galen. Both authors, we note, use the age-old 
'Battle of the Liberal Arts' format, deny any concept of a medical Renaissance based on classical texts, and happily revive medieval attitudes as grist to their mills. Only Vives, with his attack on medieval scholasticism and call for reforms in medical education, leads out into fresher terrain. But Vives receives disproportionally brief treatment (less than two pages), since the author has evidently found more interesting material in the sceptical and rhetorical topoi. The real or mock-seriousness of Agrippa's work is notoriously difficult to estimate, of course, but I ended up feeling that the polemics were superficial, easy numbers in that argumentative age.

A much more serious iconoclast and reformer is the subject of Ian Maclean's paper, 'Philosophical books in European markets, 1579-1630: the case of Ramus'. His starting point is the St Bartholomew's Day massacre of 1572 , in which Ramus was killed and his publisher André Wechel had to flee to Frankfurt, leaving a vacuum in Paris for the publication of Ramus' popular revisionist treatises. Thomas Freige, a pupil of Ramus, began the publishing war in 1573 by issuing an edition of his Ciceronianus in Basel, while the following year Wechel obtained a licence to publish books in the Imperial City of Frankfurt. As Maclean shows, Wechel tried to get a monopoly of Ramus publications by pouring out rival editions, but as his licence only protected new editions this involved him announcing in every case of reprinting that here was a 'new edition', or 'newly revised'. Awareness of the wider publishing context will alert students to the hollowness of such claims! Maclean also explains such phenomena as the Lutherans' take-over of Protestant schools at the end of the century, and their desire to reconcile Ramism with the dialectics of Aristotle and Melanchthon, resulting in books like the 1596 edition of Ramus' Dialectica, where 80 pages of text are smothered by 764 pages of commentary. The main thrust of his paper is to qualify the monolithical impression given by modern bibliographies of Renaissance philosophy (including Charles Schmitt's path-breaking one on Aristotelianism) of a single coherent intellectual tradition. Closer study, he proves, reveals a wide variety of motives in publishing (personal, financial, dynastic), affecting also the uptake of books in the market, and the range of their readership. Maclean's impressively argued and documented paper ends by asking how a bibliography could include such information. My answer would be that it can not, and that for the wider context we must turn to what might be called intellectual publishing history, of which this is a distinguished example.

\section{3}

Ian Maclean queries 'whether there can be any history of ideas without a consideration of the mediation of ideas', and wishes to open up 'the pure mental sphere of intellectual concerns' to 'social, economic, political and cultural interests'. Several contributions to the history of philosophy in this volume take such a wider range. Richard $\mathrm{H}$. Popkin studies 'The role of Jewish anti-Christian arguments in the rise of scepticism', as the traditional attempts to convert the Jews to Christianity aroused, in the sixteenth and seventeenth centuries, an answering reaction by the Jews attacking Christianity with the help of sceptical arguments. Popkin's evidence includes Bodin's Heptaplomeres, in which the stock debate between speakers of various convictions results in a victory by the Jew, and the anti-Christian polemics emerging from the Jews of Amsterdam. Popkin is a respected historian of scepticism, and his essay is full of information. However, its impact is reduced by too many garrulous and egotistic accounts of his researches, such as 'Recently 1 discovered how and when.... Before I discuss this, I should mention.... In a letter I recently found' (p. 8); or 'For some time I searched for such a library. Finally, with much help [we are not told from whom] I found...' (p. 10). Also, the author's style is often clumsy, and occasionally inchoate, as in recording his 'pleasure to have worked so long with [Charles Schmitt] on these sceptical themes, and I feel that as I pursue the leads I am now working on, I will continue to be his partner or co-worker ...'. Editorial blue pencil might have been salutary here.

Altogether tighter stylistically, with a preponderance of clipped sentences, is Charles Webster's account of 'Conrad Gessner and the 
infidelity of Paracelsus', which also invokes publishing history and the ethos of university medicine. Webster diligently reads the published correspondence of Conrad Gessner (1516-65), the celebrated encyclopedist and humanist physician, for evidence of how a largely negative picture of Paracelsus was given by medical orthodoxy, leading up to the comprehensive polemic of Thomas Erastus in the 1570s. It is unsurprising, but nevertheless saddening, to see the range of smear tactics used against Paracelsians as practitioners of demonic magic, sodomites, adulterers, papists and other heretics. A wider survey, however, would show that these are not special to the anti-Paracelsians but are normal tactics in the dirty world of sixteenthcentury controversy. It is ironic, however, that Gessner himself subsequently published recipes including what Webster somewhat anachronistically calls 'chemotherapy'. Certainly Webster is right to suggest that the dividing lines between (and within) Paracelsians and others have been too tidily drawn, although one may feel that Paracelsus continues to receive too simplistic credit, in rather Whiggish terms, as a pioneer of modern medicine.

Michael Allen, in 'Marsilio Ficino, Hermes Trismegistus and the Corpus Hermeticum', is concerned to fill out a received picture rather than challenge it, although he does note in passing that Frances Yates erroneously believed that the commentary on the Hermetic treatise Pimander published in Ficino's Opera omnia was by Ficino himself, whereas its real author (as Kristeller showed in 1937) was Lefèvre d'Etaples. Ficino translated the Corpus Hermeticum attributed to the mythical Hermes Trismegistus, and referred to the attack on statue magic in the Asclepius (actually extant only in Latin) three times in his published work. The best-known reference is in his De vita, that 'encyclopaedic treatise on how a philosopher can prolong his life and guard himself from the influence of baleful planets and their conjunctions and from the wiles of demons in their trains'. As Allen's brief summary shows, Ficino was writing within the ancient magical tradition, which offered knowledgeable practitioners the promise of personal gain in power, pleasure, or longevity. Ficino's later references to statue magic strike a more personal note, seeing Hermes as a reformer warning the Egyptians against statue worship and its attendant demonological rites. This is a carefully composed paper, complete in its own terms, which does not claim any wider significance. It is well documented, although one misses any reference to Garth Fowden's admirable study, The Egyptian Hermes. A Historical Approach to the Late Pagan Mind (Cambridge, 1986).

Ancient philosophy is the focus of Letizia Panizza's paper, 'Italian humanists and Boethius : was Philosophy for or against Poetry?' Her text is the opening of the De consolatione philosophiae, in which Boethius gives Philosophy an attack on the muses of the Prologue-poem (a song of despair, lacking reason) whom she dismisses, in terms familiar from patristic sources, as scenicas meretriculas, 'melodramatic little tarts'. Dame Philosophy goes on, however, to invoke her Muses to restore Boethius' health, and the resulting work is a mixture of prose and verse, including thirty-nine poems, most of which are sung by Philosophy herself until Boethius recovers sufficiently to emulate her. ${ }^{3}$ Although Boethius clearly validates philosophical poerry, Panizza reveals him being used for arguments in the opposition between philosophy and poetry (another dispute among the arts) over a period of three centuries. The scholastics, as she shows, adopted Boethius to support their own subordination of poetry, but from the early humanist Albertino Mussato of Padua (1261-1329) onwards, the tables were turned. Petrarch invoked Boethius to defend poetry in his Invectiva contra medicum, as did Boccaccio in De genealogia deorum (but going so far as to deny that Plato expelled the poets from his republic, suppressing what Plato said). From Salutati on to Guarino, Piccolomini, Valla, and as far as Tasso, Panizza shows how a surprisingly long and detailed tradition discussed Boethius' position. This can now be seen to be a key issue in Renaissance literary theory, of which future historians must take note.

Literature is the main focus in Lisa Jardine's

3 One puzzling point is Dr Panizza's statement that the Penguin Classics translation renders 'all poems into prose' (p. 49 note). My copy has them in verse. 
paper, 'Mastering the uncouth: Gabriel Harvey, Edmund Spenser and the English experience in Ireland', but in relation to politics, not philosophy. In 1596 the poet Spenser wrote a polemical work, A View of the Present State of Ireland, which reinforced the ruthlessly oppressive policy of the English colonizing Ireland. Drawing on some recently discovered marginalia by that inveterate self-idealizing postiller Gabriel Harvey, Jardine shows that Harvey records having studied Livy's account of Hannibal (a key topic for Machiavelli and others on whether it was permissible to use deceit in war) and related military issues, with Sir Thomas Smith and Sir Humphrey Gilbert, both connected with Irish settlement projects. Jardine suggests, hesitantly but repeatedly, the possibility of Harvey being the channel through which Spenser learned of their ideas. The suggestion seems to me entirely possible, and her detailed discussion will no doubt interest historians of colonialism. But this seems to be the paper with the least relevance to Charles Schmitt's work, and of somewhat limited scope.

Donald Kelley, by contrast, in "“Altera natura": the idea of custom in historical perspective', surveys an enormous range of material in a paper that contains the seeds of a whole monograph. The idea of custom, he shows, derives from the ancient distinction between physis and nomos, nature and law, and survives in classical rhetoric in the opposition between 'custom' (the ruler of human speech) and 'nature'. The term occurs most frequently in ancient and modern jurisprudence, from the third century $A D$ on. The Middle Ages distinguished natural law from the law of nations, which was in turn divided into a primary level (reason) and a secondary one (custom). Mere manners or usage became identified with legal or social norms, two key constituent elements being the notion of time and 'the people' (local practices). Kelley traces the idea's metamorphoses in a wide variety of texts, culminating in the Reformation's fundamental challenge to custom as being identified with 'popish (and Judaic) legalism and corruption'. Two familiar references in English literature, we can add, record this reaction. First, the protest of a late Shakespearian hero: 'What custom wills, in all things should we do't, / The dust on antique time would lie unswept, / And mountainous error be too highly heap'd / For truth to o'erpeer' (Coriolanus, II. iii. 117ff); secondly, the paranoia of the Puritans satirized in Ben Jonson's Alchemist: 'I hate traditions; I do not trust them.'

Any paper that ranges confidently from the Presocratics to Descartes is hard to follow, but Dilwyn Knox, in 'Ideas on gesture and universal languages, c. 1530-1650', is not outclassed. This too, the longest essay in the volume, carries the nucleus of a monograph within itself. Knox starts with a well-illustrated survey of gesture in the visual arts between 1250 and 1550 , before turning to the main source of theories of gesture, classical rhetoric, in which actio (or pronuntiatio, as it was also called) was the last of the five stages by which the orator formulated, memorized, and acted out his speech. Knox's account of rhetoric in the fifteenth and sixteenth centuries, where actio plays proportionally less part than in the classical texts, underlines the degree to which Renaissance rhetoric, in societies dominated by strong rulers, was becoming more of a written, less of a face-to-face democratic art. In the earlier phase there is no difference in the treatment of gesture in Protestant or Catholic manuals, the homogenized intellectual culture of Europe transcending doctrinal differences. Textbook authors tend to be rather cautious, not pushing any definite line, like Luca Baglione in L'arte del predicare (Venice, 1562), allowing 'each person to follow his natural inclination and choose the gestures that suit him'." Two factors change this situation, according to Knox: first, 'for Protestants the sermon replaced the Mass as the focus of worship'; secondly, the specialization in scholarly studies in the late sixteenth century, together with a new interest in method, produced such vast tomes as Cressolles' Vacationes autumnales sive de perfecta oratoris actione et pronunciatione (1620). While the first point may be true in general, the Catholic

4 If I may contribute my reviewer's mite here, I suggest a probable source for this idea in Erasmus' preaching treatise Ecclesiastes (1535): see the Leyden Opera omnia, 10 vols. (1703-06), vol. 5, pp. 955-6, and Jacques Chomarat, Grammaire et rhétorique chez Erasme, 2 vols., Paris, 1981, pp. 514-18, 1066. 
Church did not give up preaching, and a recent study has shown that counter-Reformation preaching manuals put far greater emphasis on emotional appeal ${ }^{5}$ - with, I imagine, a corresponding attention to gesture. As to the second, it seems to me that this is rather an instance of academic treatises proliferating around more efficient systems of information retrieval (especially among the Jesuits), with a corresponding drop in practical applications. The last topic Knox studies, the seventeenth-century schemes for universal languages, is another instance of the triumph of theory at the expense of practicality, and after Swift's memorable satire on the Academy of Laputa in Book 3 of Gulliver's Travels we may well see a reliance on signs as acknowledging the defeat of language. Still, this remarkably wide-ranging paper more than exemplifies the editors' use of Charles Schmitt as a model for 'studying simultaneously ... many different aspects of Renaissance intellectual history'.

4

Two contributions of a biographical nature complete the volume. Constance Blackwell contributes a bibliography of Charles Schmitt's publications between 1963 and 1986 of which the mere statistics are eloquent: 17 books, 117 essays, and 152 book reviews. Many of the essays have been collected, and it would be good to have the best of the book reviews, on a remarkably diverse range of topics, brought together. Beyond the statistics, of course, is a legacy that remains an inspiration and a challenge, the theme of Luce Giard's paper, 'Charles Schmitt (1933-1986) : reconstructor of a history of Renaissance learning'. This long essay (at 26 pp. the second longest) contains much valid praise for Charles Schmitt's principles and practice of intellectual history: his 'ability to pursue an investigation over a lengthy span of time', his 'conceptualization of a problem historically', his 'calm boldness in his choice of

5 See Debora Shuger, Sacred Rhetoric: The Christian Grand Style in the English Renaissance, Princeton, 1988, and my review in Arion, n.s. 1 (1990), pp. 225-8. subjects', all this 'done modestly and seriously, without bravado or theoretical proclamations'. His goal was 'deepening our understanding of the past', neither taking part in power-struggles nor going out of his way to attack those with whom he disagreed - an irenic attitude, it seems to me, which, together with a somewhat oldfashioned concept of scholarly decorum, he learned from the example of his doctoral supervisor, P. O. Kristeller. (Occasionally I wished that Charles had been less courteous, more incisive, and had spoken his mind more fully in print.) While saluting this aspect of Giard's essay I must record a personal unease at some passages which seem to me too effusive: perhaps the French language can sustain such flights, but in translation they cloy. (The translation by Maarten Ultee is clear and fluent, on the whole, but not without unassimilated Gallicisms, as in the description of Renaissance texts being written in 'pithy vernacular languages as yet poorly adapted to spiritual contest'.) And to me it seems in rather questionable taste in a piece in memory of a dead colleague and friend to push forward your own publications (pp. 272-3).

Still, Giard is to be thanked for her generous tribute, to which many readers will want to contribute their own memories. My strongest impression, whether visiting him in his room at the Warburg or having a tea-break from some conference in Ferrara or Washington, DC, was of a mind wholly absorbed in acquiring and communicating a fuller and better-grounded reconstruction of an intellectual climate in the past, and of the various factors that created or sustained it. His conversation was dedicated not to personalities but to issues of knowledge, and as one tentatively broached a topic he would sometimes break in with a sentence beginning 'See' - before outlining his latest thoughts, or most recent reading. There was an admirable lack of fuss, an absence of self-regard, a fixing of the eye on the object, that encouraged all who heard him talk or read his writings to do the same. The tribute that John Henry and Sarah Hutton have brought to fruition speaks of Charles's belief in 'an unificationist view of Renaissance intellectual history', the sense that one might start a project in the field of rhetoric and end up in the history of science, that for that 
period the researcher must be prepared to follow his or her subject wherever it leads. While scholars of his range and depth will always be rare, the evidence of this volume suggests that the enterprise itself is in good hands.

Brian Vickers

Centre for Renaissance Studies, ETH-Zentrum,

Rämistrasse 101, CH-8092 Zürich 